\title{
Lost Trust? The Experiences of Teachers and Students during Schooling Disrupted by the Covid-19 Pandemic
}

Tijana Jokić Zorkić ${ }^{\star 1}$, Katarina Mićić ${ }^{2}$ And Tünde Kovács Cerović ${ }^{2}$

$\approx$ This paper aims to help understand how relational trust between students and teachers embedded in the teaching-learning process unfolded during the emergency distance and flexible hybrid education in Serbia in 2020. It also identifies niches in student-teacher relationships that hold potential for repairing and building trust. For the student-teacher relationship to be trust-based and thus conducive to students' learning and wellbeing, a consensus about role expectations must be achieved. As the Covid-19 crisis interrupted schooling and education, participants faced uncertainties and ambiguities in role enactment, and the cornerstones of relational trust were disrupted. In an effort to understand 1) the context in which trust was challenged, 2) the ways in which trust was disrupted, and 3) the opportunities for its restoration, we relied on a multi-genre dynamic storytelling approach to data collection and values analysis for data processing. A total of 136 students and 117 teachers from 22 schools wrote 581 narratives in three genres: stories, letters and requests. The analysis yielded 22 codes that allowed further understanding of how changes in structural and institutional conditions affected both students' and teachers' expectations of each other, and how incongruence of these expectations fed into feelings of helplessness for both students and teachers, disengagement from learning for students, and heavy workload and poor performance for teachers. In addition, the narratives account for positive outcomes when these expectations were met, and for opportunities for trust-building if students' and teachers' perspectives are brought to each other's attention and negotiated locally. Finally, recommendations for restoring trust are given.

Keywords: disruption of relational trust, remote and hybrid education during the pandemic, dynamic storytelling, analysis of narratives, students' and teachers' perspectives

$1{ }^{\star}$ Corresponding Author. Centre for Education Policy, Serbia; tijana.z.jokic@gmail.com.

2 Faculty of Philosophy, University of Belgrade, Serbia. 


\section{Izgubljeno zaupanje? Izkušnje učiteljev in učencev med šolanjem, ki ga je prekinila pandemija covida-19}

Tijana Jokić Zorkić, Katarina Mićić and Tünde Kovács Cerović

$\approx$ Namen prispevka je pomagati razumeti, kako se je odnosno zaupanje med učenci in učitelji, vgrajeno $\mathrm{v}$ proces poučevanja in učenja, razvijalo med izrednim izobraževanjem na daljavo in prilagodljivim hibridnim izobraževanjem v Srbiji leta 2020. Opredeljuje tudi situacije v odnosih med učenci in učitelji, ki imajo potencial za obnovo in krepitev zaupanja. Da bi odnos med učencem in učiteljem temeljil na zaupanju ter tako pripomogel $\mathrm{k}$ učenju in dobremu počutju učencev, je treba doseči soglasje o pričakovanjih glede vlog. Ker je kriza covida-19 prekinila šolanje in izobraževanje, so se udeleženci spoprijeli z negotovostjo in dvoumnostjo pri uveljavljanju vlog, porušeni pa so bili tudi temelji odnosnega zaupanja. Da bi razumeli kontekst, v katerem je bilo zaupanje postavljeno pod vprašaj, načine, na katere je bilo porušeno, in priložnosti za njegovo ponovno vzpostavitev, smo se pri zbiranju podatkov oprli na večvrstni pristop dinamičnega pripovedovanja zgodb, pri obdelavi podatkov pa na analizo vrednot. Skupaj 136 učencev in 117 učiteljev iz 22 šol je napisalo 581 pripovedi treh vrst: zgodbe, pisma in prošnje. Analiza je dala 22 kod, ki so omogočile nadaljnje razumevanje, kako so spremembe strukturnih in institucionalnih pogojev vplivale na medsebojna pričakovanja učencev in učiteljev ter kako se je neskladnost teh pričakovanj odrazila v občutkih nemoči pri učencih in učiteljih, neudeležbi pri učenju pri učencih ter v veliki delovni obremenitvi in slabi učinkovitosti pri učiteljih. Poleg tega pripovedi opisujejo pozitivne rezultate, ko so bila ta pričakovanja izpolnjena, in priložnosti za krepitev zaupanja, če se na stališča učencev in učiteljev opozori ter se o njih pogaja na lokalni ravni. Na koncu so podana priporočila za ponovno vzpostavitev zaupanja.

Ključne besede: prekinitev odnosnega zaupanja, izobraževanje na daljavo in hibridno izobraževanje med pandemijo, dinamično pripovedovanje zgodb, analiza pripovedi, stališča učencev in učiteljev 


\section{Introduction}

The year 2020 was exceptional for education systems globally. The Covid-19 pandemic led to unprecedented disruptions in schooling around the world (Bertling et al., 2020), which exacerbated already known education policy fractures and put the quality, equity and effectiveness of education at risk (Schleicher, 2020). It forced school closures, the introduction of emergency distance education, and experimentation with various hybrid and blended educational models, thus leaving more than 1.5 billion children temporarily out of school (UNESCO, 2020a) and exposing all education participants to an incommensurable degree of uncertainty and ambiguity (Bergdahl \& Nouri, 2020; Gudmundsdottir \& Hathaway, 2020; Hodges et al., 2020; Trust \& Whalen, 2020).

Teachers were at the forefront in the abrupt change in their everyday practice (Reimers \& Schleicher, 2020). The dissolution of the education setting, their professional role and their work habits are all potential high stressors for teachers (Kim \& Asbury, 2020). Teachers were the first to face the challenges of technological, content, pedagogical and monitoring readiness (UNESCO, 2020a), all subsumed in conducting distance education. In doing so, teachers' basic psychological needs for autonomy, competence and relatedness were jeopardised (Kim \& Asbury, 2020). They were coping with a multitude of new requirements under conditions that stripped them of feedback from students and drove them to a high risk of burnout (Hargreaves \& Fullan, 2020). At the same time, teachers were also citizens, facing the same dilemmas, threats and anxiety as everyone else, and overseeing the home schooling of their own children while enacting their school-teacher role. Nevertheless, teachers' positive experiences were also detected, such as "increased flexibility in learning and teaching, more opportunities for differentiation in lessons, and increased efficiency in working, teaching, and learning" (van der Spoel et al., 2020, p. 629). Teachers also reported transformative experiences of finding a way out of uncertainty (Kim \&Ashbury, 2020), discovering that "schooling is about much more than learning" (Moss et al., 202O, p. 4) and understanding the socio-emotional needs of students and the community both during school lockdown and in discovering how to deliver a blend of physical and remote teaching (Moss et al., 2020).

Students' experiences are less often documented. Especially concerning was the fact that at least one third of students globally were excluded from distance education (UNICEF, 2020). Many studies point to the consequences of unequal access to distance education in terms of losses in students' learning and wellbeing (Bertling et al., 2020), and consequently to potential long-term lapses in countries' economic development (Hanushek, 2020). Mostly studies 
focusing on students' mental health and wellbeing have been conducted thus far, pinpointing emerging behavioural problems (Loades et al., 2020; Orgiedes et al., 2020), while students' experiences of the learning process in the context of school lockdown are still rare. Studies that include students portray the educational hardships they face in distance education as well. For example, Niemi and Kousa (2020) report how the tasks and requirements reaching the students were felt as demanding and overwhelming throughout several weeks, while teachers did not register or acknowledge the burden students felt. Distance education can also trigger reliance on student self-regulation and self-motivation (Kovacs Cerović et al., 2021), but not if students are without adequate support (Černe \& Jurišević, 2018).

The disruption and transformation of schooling elicited strong reactions from all education participants. The medical threat and feelings of frustration and/or exploration regarding the new situation had the potential to strongly unite teachers and students and create a strong transformational partnership in facing and overcoming the hardships. On the other hand, the isolation and remoteness resulting from school closure and stress had the potential to move the participants in quite the opposite direction. The disruption also created new niches to explore how the education process twists, transforms or deteriorates in unforeseen ways and gets reinterpreted and (hopefully) reconstructed by the education participants.

\section{Relational trust}

According to Bryk and Schneider (2002), relationships between teachers and students, teachers and other teachers, teachers and parents, and between all of these actors and the principal, are characterised by mutual dependencies in the effort to achieve desired outcomes. These dependencies are attached to school actors' understanding of the roles and obligations of others, as well as to expectations they hold of each other. Therefore, for a school community to be successful, a consensus about roles, obligations and expectations must be achieved in all role relationships.

Such relational trust is grounded in respectful exchanges between school actors, genuine listening and taking others' views into consideration in subsequent actions, which make all school actors feel valued and respected. Competence in core role responsibilities is what produces desired outcomes and thus meets others' expectations. Moreover, holding each other in personal regard discerns trust as it spurs from the willingness of actors to enact more than just what the professional role requires (e.g., openness to others). In addition, perceptions 
about personal integrity (e.g., keeping one's word, moral-ethical perspective) affect school actors' judgments of trustworthiness (Bryk \& Schneider, 2002).

\section{Benefits of relational trust}

An abundance of research results demonstrate multiple benefits of relational trust in the context of educational changes, school improvement and student achievement and wellbeing.

Relational trust is at the core of teachers' experience of educational change (Bryk \& Schneider, 2002; Cranston, 2011). Trust-based relationships with colleagues and principals make professional learning communities adapt to the continuously changing demands (Cranston, 2011; Tschannen-Moran, 2009), while teachers' perceptions of personal integrity (Louis, 2007; Tschannen-Moran \& Gareis, 2015) as well as their perception of the professional competence of change administrators influence teachers' willingness to take risks and to test untested hypotheses (Bryk, 2010; Tschannen-Moran, 2009).

Collegial trust among teachers has also proven to influence teachers' commitment to students (Lee et al., 2011); the collaborative community provides opportunities for teachers to share experiences, ask for support and get feedback from colleagues, which in turn enhances their efficacy on instructional strategies and student discipline.

Consequently, students benefit from teachers' trust and their achievements are likely to increase, even in poverty-stricken schools (Goddard et al., 2001; van Maele \& van Houtte, 2011). Moreover, students' sense of wellbeing strengthens when schools encourage and promote authentic forms of students' voices that warrant students' psychological and emotional involvement in schooling (Smyth, 2006).

Students also benefit from their own trust in teachers in terms of learning and achievement (Goddard et al., 2001; Goddard, 2003) as well as prevention and mitigation of discipline problems (Gregory \& Ripski, 2008); when students are confident in their expectation that teachers act reliably and competently, their engagement within the learning processes is higher.

However, relational trust is moderated by contextual factors. A history of untrustful role-relationships within a school community is a barrier to the development of relational trust in the present. Institutionalised mistrust, such as negative long-term experiences with school leadership (Tennenbaum, 2018) or distrust in the system in general (Louis, 2007), prevent the establishment of relational trust between education participants.

Another moderator of trust between school actors is the positional power they bear. In other words, more powerful actors hold trust for others based 
on the perceptions of their competence, while more dependent actors give trust based on perceptions of more personal characteristics (Weinstein et al., 2018). For example, teachers' trust in students is associated with their perceptions of the students' ability to meet their expectations, while students' trust in teachers is predicted by their experiences of trust teachers attribute to them (van Maele \& van Houtte, 2011).

\section{The Covid-19 crisis and relational trust}

Relational trust becomes even more important in times of crisis, such as the Covid-19 pandemic, as the risks are greater and the stakes are higher (Myung \& Kimner, 2020). Relational trust between school actors embedded in the culture of safety and respect is therefore of utmost importance for organised, quick and effective change, as it is conducive to the participants' resilience and school improvement (Myung \& Kimner, 2020).

To the best of our knowledge, research on relational trust in the context of the Covid-19 crisis does not yet exist. However, appeals for its establishment and maintenance, throughout school closure and especially during school reopening, have been noted. Myung and Kimner (2020) call for shared purpose, mutual trust, structures and resources that foster collaborative work. Viner et al. (2021) advocate health and protection protocols that maintain the trust of teachers, students and the public in education institutions. Darling-Hammon and Hyler (2020) appeal to policymakers to develop strategies that support educators in meeting the socio-emotional and academic needs of students (e.g., supporting mentoring and the development of new teacher roles, and creating time for educators to collaborate with each other and key partners).

\section{Education during the pandemics in Serbia}

During the 2020 pandemic, Serbian schools used two different approaches. As in many other countries in Europe and worldwide (UN, 2020), full school closure with distance education started in mid-March and lasted until the end of the school year. In autumn, a flexible hybrid approach was introduced, combining contact instruction (albeit with reduced hours and class size) with distance learning, allowing schools to design the option that fitted their students' needs and school capacities best, and allowing parents to individually choose the type of instruction they preferred for their child. The two approaches to schooling were not only different in organisation, but were also embedded in two different contexts. In spring, a six-week state of emergency with a major lockdown and a harsh curfew was enforced in parallel with school closure, 
while autumn brought a return to near normal organisation of life, albeit with social distancing, masks and no nightlife. Distance education during the school closure and as part of hybrid education included a combination of low-tech and high-tech tools from the UNESCO suggested list (UNESCO, 2020b), such as TV instruction, Viber groups, email, Messenger, Google Classroom, Google Meet or Zoom, but occasionally also no-tech solutions of providing printouts for parents or students to pick up at the school entrance.

\section{Research goals and questions}

Given the pricelessness of relational trust in times of crisis and the dynamics of education provision in Serbia during 2020, we wondered how teacher-student interactions unfolded and what expectations were involved. Did the transformed education process instil relational trust and trust in education itself, or did it challenge it?

This paper puts the spotlight on the intricacies of the teaching-learning process and the relational trust embedded in it from the perspective and through the experiences of schoolchildren and teachers during the school closure and reopening in Serbia in 2020. The paper aims to help understand how relational trust between students and teachers was unfolding, distilling, diminishing, or reconstructing itself during emergency distance and flexible hybrid education experienced.

The research questions that guided this research endeavour are:

1. How did students and teachers experience distance and hybrid education?

2. Was trust disrupted and, if so, how?

3. What are the opportunities for repairing and strengthening relational trust in this challenging context?

\section{Method}

As the aim of our study called for exploring nascent experiences saturated with feelings and search for meaning, we selected a narrative methodology that utilises the dynamic storytelling approach (Daiute \& Kovač-Cerović, 2017) as a data collection framework, and Values Analysis (VA) (Daiute, 2013; Daiute et al., 2020) as a type of qualitative analysis that fully respects the narrators' stances. This analysis builds on the understanding that narration is a communicative act and that narrative expressions communicate messages and meanings that the narrator chooses as important and valuable to share. Therefore, VA 
does not refer to the social-psychological notion of value, but to the communicative value of a message. Furthermore, guided by our interest in delving into the intricacies of the interactions between key education participants, we opted for multi-genre narratives. As prior research has proven (Daiute \& Kovač-Cerović, 2017), different narrative genres provide opportunities for narrators to relate to different actual or imagined audiences with dynamic, different and even contradicting stances and voices, thus enriching the perspectives conveyed.

\section{Data collection: Instrument and procedure}

We constructed an online instrument containing prompts for narratives and basic group identifiers. The prompts for both teachers and students were designed to elicit narration in two different genres: in the form of a story about schooling in the altered conditions, and in the form of a letter to a peer who is about to face schooling in altered conditions. We additionally prompted students to narrate in a request genre by writing about what they would like to be different in the current schooling conditions.

Both instruments were disseminated online to schools in two waves: first in June 2020, during the lockdown and distance education only, and several months later, in December 2020 and January 2021, when education was organised in a flexible hybrid model. In both waves, links to online instruments were distributed via school management and participation was voluntary.

\section{Sample of participants and narratives}

A total of 136 students and 117 teachers from 22 schools completed the questionnaires in two waves. In the first wave (June 2020), 45 students (64\% female, average age 14.3) and 59 teachers ( $94 \%$ female, average work experience 15.9 years) took part in the study. In the second wave, another 91 students (59\% female, average age 11) and 58 teachers ( $85 \%$ female, average work experience 15.5 years) participated in the research (no first-wave participants took part in the second wave of data collection). The participants wrote a total of 581 narratives. Table 1 shows the sample of narratives per wave, subsample of participants, and narrative genre. 
Table 1

Sample of narratives per wave, subsample of participants, and narrative genre

\begin{tabular}{|c|c|c|c|c|c|c|c|}
\hline \multirow{4}{*}{$\begin{array}{l}\text { Distance } \\
\text { learning }\end{array}$} & \multicolumn{3}{|c|}{ Students } & \multicolumn{2}{|c|}{ Teachers } & \multirow{4}{*}{213} & \multirow{8}{*}{581} \\
\hline & Stories & Letters & Requests & Stories & Letters & & \\
\hline & 36 & 30 & 39 & 54 & 54 & & \\
\hline & & 105 & & & & & \\
\hline \multirow{4}{*}{$\begin{array}{l}\text { Hybrid } \\
\text { model }\end{array}$} & \multicolumn{3}{|c|}{ Students } & \multicolumn{2}{|c|}{ Teachers } & \multirow{4}{*}{368} & \\
\hline & Stories & Letters & Stories & Letters & Stories & & \\
\hline & 79 & 87 & 89 & 57 & 56 & & \\
\hline & \multicolumn{3}{|c|}{255} & \multicolumn{2}{|c|}{113} & & \\
\hline
\end{tabular}

\section{Analysis}

The narrative materials were segmented into thought units, usually consisting of one sentence per unit, which were coded. A coding manual was developed after the first wave of data collection. Three researchers collaboratively read a sample of materials to identify the organising principles and important messages, i.e., "values" communicated through each unit, and to assign codes and then fine-tune the coding system on another sample of materials. A sample of the narratives from the second wave was used to adjust the coding manual to newly emerged values. Prior to final coding, a reliability check was carried out. Cohen's Kappa coefficient showed a strong agreement between two coders $(\kappa=0.82, p=.000)$, who further coded the materials from both waves.

\section{Results}

A total of 2,346 thought units were coded with 22 codes, subsequently grouped into two broad themes: context and trust. The context theme is organised around codes that refer to the experiences of conditions set by the pandemics during distance and hybrid education, while trust is thematised through codes representing relations, perceptions and evaluations of self and others, around which trust is devised.

The distribution of the 22 codes in the complete sample of coded thought units (across both stakeholders and both waves of data collection) is shown in Figure 1. The three pivotal codes emerging from students' and teachers' narratives, regardless of the education model, are Learning process and 
outcomes (14.1\% of all coded units), Unusual way of schooling (11\%), and Heavy workload (9.6\%), while eight codes are distributed with frequencies close to $5 \%$, and another eleven with lower frequencies, all calling for further detailed analysis.

The detailed meaning and content of all of the codes within the two themes is described in the next section, where answers to the research questions are presented. Distributions of codes by stakeholders and education models for context and trust are shown in Figures 2 and 3, respectively.

\section{Figure 1}

Distribution of coded thought units across two broad themes (Characteristics of context, and Dimensions of trust)

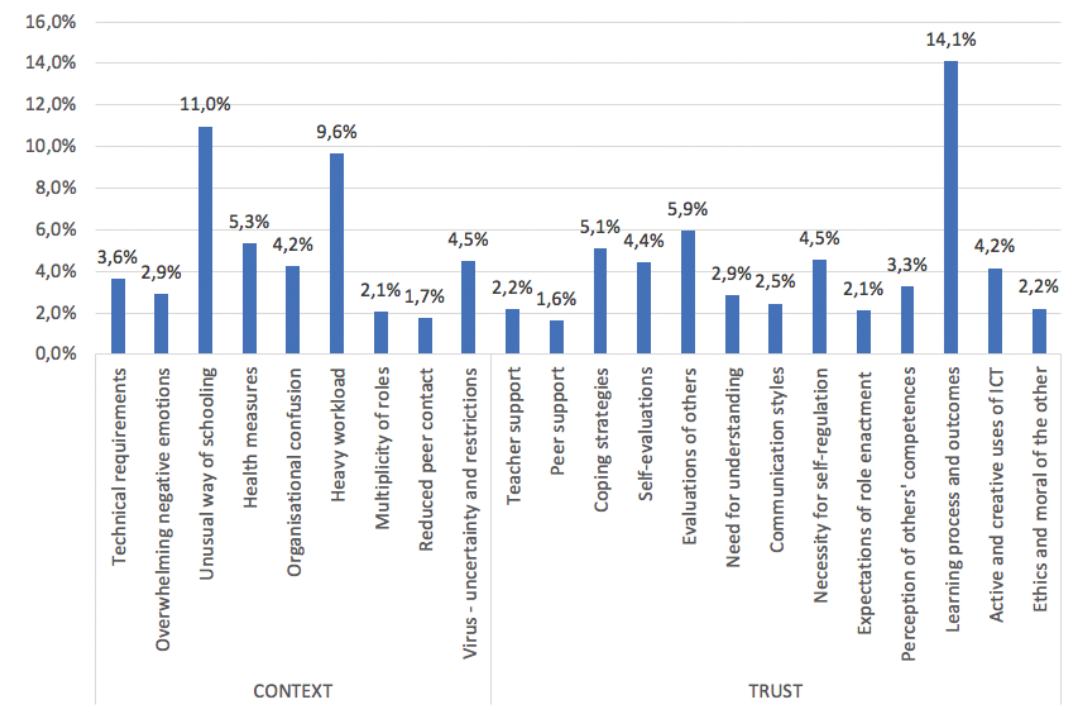




\section{How did students and teachers experience distance and hybrid education?}

\section{Figure 2}

Distribution of codes within Context across research participants' narratives and waves of data collection

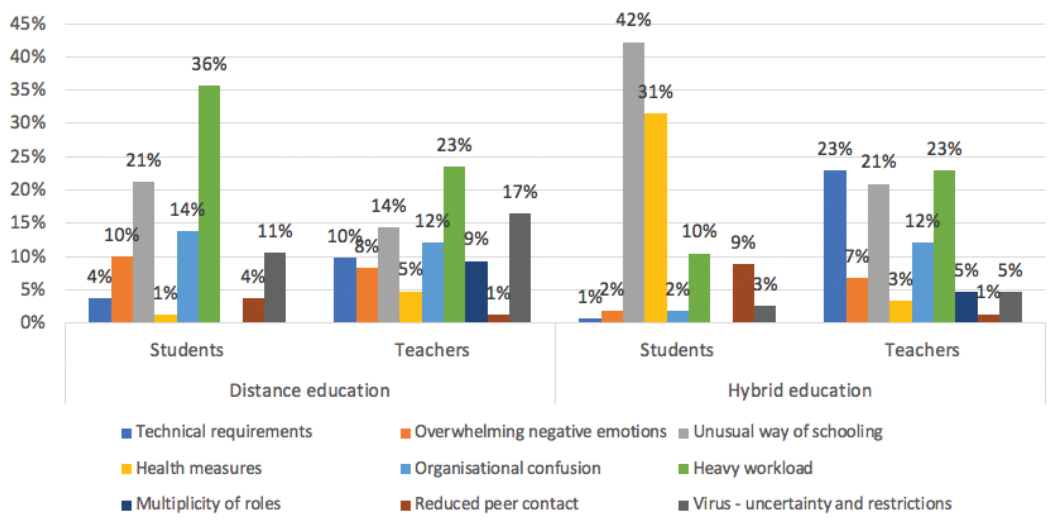

Both students' and teachers' narratives most frequently point to the heavy workload during distance education (Figure 2; code: Heavy workload; $36 \%$ of units in students' narratives and $23 \%$ of units in teachers' narratives), and how unusual (code: Unusual way of schooling) and confusing (code: Organisational confusion) it was. Students' expressed that they were overwhelmed with homework, and that too many different online platforms had to be used, which made it impossible to keep up with all of the teachers. One student summed this up as follows: "every week is more challenging than the other, every assignment harder than the previous, every piece of homework bigger, and all that without teachers to help you" (student Marija). Similarly, teachers described a surplus of obligations resulting from unclear top-down guidance, unequal outreach to students, and their lack of digital skills. One teacher portrayed this period as a "virtual darkness with no access to feedback of any kind" (teacher Vesna). Additionally, many teachers struggled to balance two very important roles (code: Multiplicity of roles) - teacher and parent - and, more frequently than students, they narrate about the anxiety caused by contradictory discourses about the virus (code: Virus - uncertainty and restrictions). Both students and teachers faced many technical problems: lack of equipment or outdated equipment, poor internet connection, sharing ICT devices with siblings and family (code: Technical requirements). 
School reopening and the transition to a hybrid model of schooling was less demanding and confusing for students, similarly demanding and confusing for teachers, but significantly more unusual for both (Figure 2): "this hybrid model makes no sense" as one student said (student Borko). Unusual and ambiguous students' experiences are related to the restrictive health measures (code: Health measures) of in-person instruction (e.g., short in-person lessons and half-empty classrooms), and to the mismatch between TV lessons and school-based work (code: Organisational confusion), which all somehow conveyed a lack of much needed contact with peers and teachers (code: Reduced peer contact). For teachers, this model triggered feelings of "helplessness in a controlled chaos" (teacher Slavica).

These results show that the transition to distance teaching as well as the hybrid model of education brought many uncertainties and ambiguities in the enactment of students' and teachers' roles (Figure 2; code: Overwhelming negative emotions).

\section{Was trust disrupted and, if so, how?}

The narratives describe how all four core dimensions of trust in student-teacher relationships were disrupted: competence, respect, personal regard and integrity (Bryk \& Schneider, 2002). In this section, we describe students' accounts of student-teacher relationships in relation to the four trust cornerstones and contrast them with teachers' views.

\section{Figure 3}

Distribution of codes within Trust across the research participants' narratives

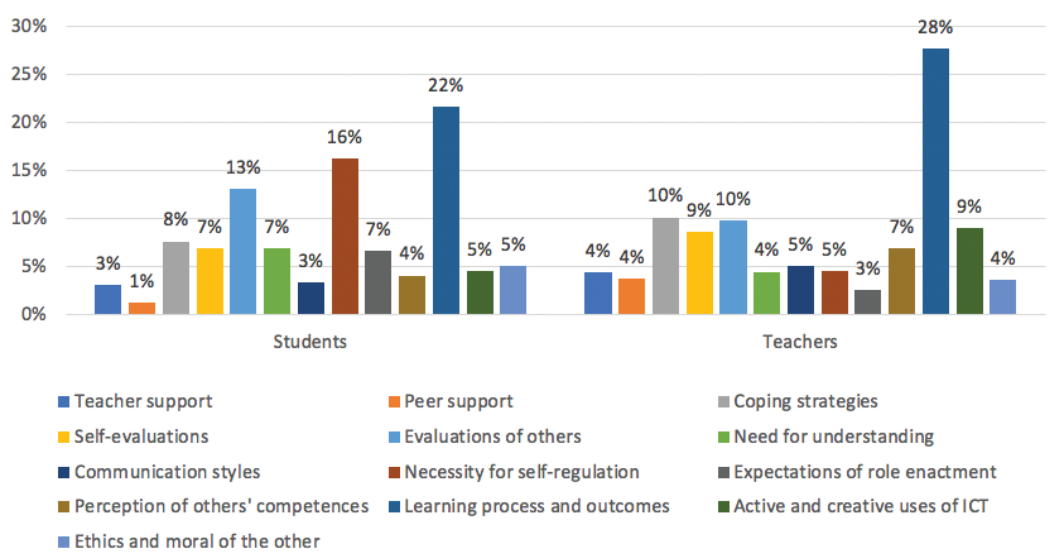




\section{Competence}

This is the most elaborated dimension of trust by both students and teachers and can be traced through 7 out of 13 codes: Coping strategies, Self-evaluations, Evaluations of others, Necessity for self-regulation, Perception of others' competence, Learning process and outcomes (a code prominent in all subsamples), and Active and creative uses of ICT.

Students refer to the quality of distance and hybrid education (Figure 3, code: Learning process and outcomes), the (in)competence of teachers (code: Perception of others' competence), the need for self-regulation of learning (code: Necessity for self-regulation), and to much needed creative uses of ICT in education (code: Active and creative uses of ICT). They assess the changed schooling as not very effective, as they generally felt "less actively involved in learning" (student Alisa), and perhaps even more so in hybrid education. The incompetence of teachers is seen through underused features of digital platforms, applications and video chats. On the other hand, they describe cases of teachers' creative uses of ICT that helped them learn, develop new skills and feel good about education (codes: Active and creative uses of ICT and Self-evaluations).

The code Learning process and outcomes in teachers' narratives is most frequently elaborated in terms of the equity of distance education as well as their own contribution to this dimension. For example, they explain how unequal students' participation was due to the unequal distribution of resources, and how now more than ever it was important for teachers to get to know their students, to praise their work and engagement, to find ways to motivate them, and to make careful and creative choices about teaching methods and learning materials. Additionally, teachers speak about their digital (in)competence (codes: Coping strategies, Self-evaluations, Active and creative uses of ICT): how the digital environment is unfamiliar to them, how collegial exchanges helped them find their way around digital platforms, how they need to further develop digital skills, how (un)creatively they used digital technologies, and why they should be used more in the future.

Some narratives illustrate how organisational, technical and logistical day-to-day problems prevented teachers from responding to students' needs on time and from devoting themselves more to capacity building (codes: Necessity for self-regulation, Coping strategies): "each time you think you're on the right track, you know that an incoming instruction from the Ministry will push you into a ditch" (teacher Borjana). 


\section{Respect}

Students' and teachers' accounts of mutual respect differ in their focus. Students point more frequently to disruptions, while teachers also elaborate their efforts to establish caring exchanges. Codes that inform understanding of respect are Need for understanding and Communication styles.

The sources of disruption pointed out by students are similar across time (distance and hybrid model). Disruptions occurred when teachers expressed anger, resentment or lack of patience (Figure 3, code: Communication styles, e.g., when homework was not submitted on time) or when they expressed demands that the students perceived as beyond their capacities (code: Need for understanding, e.g., long tests in a very short time). In their narratives, students asked for more understanding and patience, and a better mood from teachers, as "some teachers are more hostile than before" (student Nenad). The notions of disrespect in communication found in the students' narratives may indicate disruptions in this dimension (code: Communication styles): "If students don't respect you, this is because you disrespect them" (student Lena).

Teachers narrate about attempts to find ways to include all students in daily exchanges, especially at the beginning of lockdown, to maintain caring communication, to show understanding, to convey the importance of mutual support, and to teach them empathy (codes: Communication styles and Need for understanding). Teachers also suggest how respectful communication on the part of students is lacking (code: Communication styles) - politeness, nice behaviour, discipline, listening to what teachers are saying - which is mostly related to behaviour during lessons. However, teachers' considerations of respectfulness of their own communication related to instruction or assessment were not noted.

\section{Personal regard}

Students and teachers do not talk explicitly about the willingness of others to enact more than what their roles require. However, this can be understood through codes such as Teacher support, Peer support, Expectations of role enactment, and Communication styles.

Students thus talked about the readiness of teachers to support them in resolving the same problems repeatedly, and about their availability for communication at all hours (Figure 3, code: Teacher support): "The good thing is that our teacher did his best to explain the lesson before and then again after the test" (student Neda).

Some teachers describe their perception of students' responsibility (code: Expectations of role enactment). In doing so, they refer to their expectations 
that education should have been the students' priority during the pandemic, and that students should be motivated and have working habits. It was therefore especially rewarding for teachers when students, despite all of the obstacles, succeeded in responding to all of the assignments and in staying motivated throughout the lockdown, while their failing to live up to these expectations made teachers feel less valued and respected: "I feel bad and helpless because children won't turn their cameras on during lessons and they cheat with homework" (teacher Dara).

\section{Personal integrity}

Perceptions of personal integrity are also related to instruction and assessment in both the students' and teachers' narratives, and are highlighted through the code Ethics and moral of the other. Almost all notions refer to experiences during school closure and distance education.

Students speak of a difference in power positions and point to times when "some teachers make claims and act inappropriately, just because they can" (student Veljko), which they see as unjust. In turn, they tend to withdraw from interaction and to meet only minimum requirements for that particular subject.

Teachers note the unethical conduct of students, such as family members doing the homework instead of students or students making up unrealistic excuses for their absence in online education. One teacher stated that they have been assessing "moms, dads, older siblings, good aunts and helpful neighbours" (teacher Bojana). This was very challenging for teachers, as they had to intensify communication with parents, who negate such behaviours, while at the same time trying to avoid negative assessment in order to prevent adding burden and negative feelings in already hard times.

\section{What are the opportunities for repairing and strengthening relational trust?}

Although the results presented thus far point to disruptions of all four cornerstones of trust, niches that safeguard opportunities for repairing trust between students and teachers are registered too.

Similarities and differences in the discernment of codes that are relevant to relational trust across students' and teachers' narratives can be noted across waves. During school closure, comparable discernment through the narratives was found in relation to Learning process and outcomes (about 20\% of the coded units in students' and teachers' narratives). During hybrid education, 
however, teachers' accounts of Necessity of self-regulation become more frequent, thus approaching its distribution in students' narratives (about 10\% of the coded units). Similarly, the frequency of students' accounts of Coping strategies came closer to its distribution across teachers' narratives in the second wave (hybrid education).

These niches hold potential for restoring trust if they are brought to the attention of and negotiated by students and teachers.

\section{Commitment to learning goals and outcomes should be negotiated}

Caring communication on the part of teachers and openness towards providing socio-emotional and learning support makes students feel more comfortable and safer in times of crisis and strengthens their confidence in teachers' devotion to students' advancement. For example, students' words such as "we are not going to bother you... please don't get angry with us... it hasn't been a month since we started school... I hope we will get on with each other well” (student Marko) or "don't get angry with us if we don't complete assignments on time, not all of us have equal access to online platforms" (student Jovana) can be translated into teachers' notions such as "we should have in mind that some students are not digitally competent and that they need more support... also, not all students have equal access to online teaching... be patient because they will ask for support a lot!" (teacher Fatima).

\section{Expectations of role relationships should be agreed}

Students' demands for creative uses of online platforms and digital technologies by teachers, as this actively engages them in learning, should be met with understanding and competence by teachers. As one teacher explained: "Don't expect students to be online every day at the same time. They should learn at their own pace. Set realistic deadlines. Give new assignments on particular days, not every day, and choose them according to the outcomes you want to achieve... take kids to virtual museums... enjoy students' work and products..." (teacher Sofija).

On the other hand, students' owning the responsibility for their own learning and ethical conduct leverages teachers' trust and commitment to students. Some students explained how distance learning was not too hard, as they "followed certain rules during the whole semester: behave respectfully towards teachers, actively participate in lessons, and study regularly" (student Milica). 


\section{Discussion and policy recommendations}

In this section, we discuss the meaning and significance of the results in light of prior research on relational trust. In addition, we relate the results to considerations of systemic measures that can contribute to trust building between students and teachers.

\section{Discussion}

This research described how relational trust between students and teachers - as defined by Bryk and Schneider (2002), i.e., consensus about roles, obligations, and mutual expectations - became ruptured during the emergency distance and hybrid education in Serbia in 2020.

Firstly, our data bears witness to the manifold challenges for the enactment of both students' and teachers' roles created by the transition to distance and hybrid education. Students narrate about overwhelming amounts of homework and negative and ambiguous emotions, while teachers speak about a surplus of obligations and feeling of helplessness. At the same time, they all encounter numerous technical problems. Similar experiences were noted in other research that included students and teachers during the Covid-19 crisis: losses in wellbeing, feeling of belonging, and confidence in their competences (Bertling et al., 2020; Kim \& Asbury, 2020; Niemi \& Kousa, 2020; Trust \& Whallen, 2020).

The fear and uncertainty that everyone faced needed to be mended and overcome through peer, collegial and teacher-student exchanges. However, as our findings suggest, trustful social exchanges were rarely available to students and teachers. All four cornerstones of relational trust were compromised during the period of distance and hybrid education: competence, respect, personal regard and integrity (Bryk \& Schneider, 2002).

Students described how a lack of confidence in teachers' competences diminished relational trust. They assessed that teachers' underdeveloped competences in the online environment negatively influenced students' engagement in meaningful learning, much as has been found in the case of face-toface instruction (e.g., Goddard et al., 2001). Moreover, teachers' abuse of their power position (lack of personal integrity) negatively affected students' trust in teachers: students withdrew from interaction and met only minimal class requirements. On the other hand, students described positive emotions and engagement in schooling when they perceived teachers' respectful communication and readiness to support students (respect and personal regard). These 
results suggest that when teachers encourage students' expression and psychological and emotional involvement in schooling, students' sense of wellbeing is strengthened (Smyth, 2006), including during education in times of crisis.

For teachers, students' inability to meet the expectations of being motivated and persistent in learning during distance and hybrid education prevented them from holding students in high personal regard and consequently affected relational trust between them. The same happened when teachers perceived a lack of personal integrity among students (e.g., unethical conduct) or disrespect in communication (e.g., impoliteness). According to the literature on relational trust (van Maele \& van Houtte, 2011; Weinstein et al., 2018), teachers' divulging trust to students based on the perception of their competence is a common feature of contact instruction, while students more often give trust to teachers based on their personal characteristics (e.g., personal integrity). However, our research showed that both competence and more personal cornerstones of trust, such as personal regard, respect and integrity, are a very powerful basis for trustful role-relationships between teachers and students in times of crisis.

An important finding is how collegial exchanges during this time helped teachers in relation to capacity building and navigating the rapidly changing and overwhelming context. As previous research has shown, horizontal exchange and collaboration correlate with teachers' resilience in times of crisis (Cranston, 2011; Tschannen-Moran, 2009).

The findings also point to how contextual features moderated relational trust (Louis, 2007; Tennenbaum, 2018). According to teachers, the frequent but conflicting top-down demands created a surplus of administrative obligations to be fulfilled within tight deadlines. These tasks often prevented them from responding to students' needs or establishing caring and empathic communication with them. Teachers report knowing that this led to students' disappointment, but they also felt a lack of understanding on the part of students, feelings that altogether jeopardised relational trust.

As other authors have noted, shared purpose and mutual trust (Myung \& Kimner, 2020) as well as meeting the socio-emotional and academic needs of students (Darling-Hammond \& Hyler, 2020) are conducive to school actors' resilience and school improvement in times of crisis. In line with this, the results of the present research point to opportunities for strengthening the culture of safety and respect in schools, which is profoundly important for the Covid-19 education process. Negotiation of commitment to learning goals and outcomes, as well as consensus on expectations of role relationships, can contribute to students' and teachers' resilience and wellbeing during crisis, students' greater engagement in schooling, teachers' commitment to students, and more positive 
overall teacher experience of rapid change. With this in mind, we provide policy recommendations below.

\section{Policy recommendations}

Clear and timely guidance from education authorities. According to teachers' narratives, frequently changing and confusing top-down instructions prevailed even during hybrid education. Policymaking should thus establish a clear framework for emergency and remote teaching in terms of goals and outcomes, curriculum, platforms and assessment, with margins for possible directions of changes due to the evolving health situation. Guiding and support sessions and materials for teachers are also needed in order to reduce uncertainty and confusion. In turn, we expect, students' perceptions of teachers' competence and integrity would not be as compromised as they are now (Lee et al., 2011; van Maele \& van Houtte, 2011), and their engagement in learning would increase (Goddard et al., 2001; Goddard, 2003).

Building pedagogical digital competences of teachers. Both teachers and students pointed to the drawbacks and benefits of (ill-)prepared instruction, and (un)transparent assessment in distance and hybrid education, in terms of learning outcomes. Well-designed inclusive instruction in the digital environment is related to the culture that teachers build around implementing technology (McMahon \& Walker, 2019), which is embedded in the school context and local realities (Kovacs, 2018), as well as in wider societal discourses on digitalisation in education (Vivitsou, 2019). Therefore, capacity building should aim to develop pedagogical skills in the digital environment, formative assessment, and a relational approach to instruction and learning (UNESCO, 2020a), and it should be articulated in horizontal exchange and collaboration within schools, allowing for the exploration of teachers' preconceptions and previous practices of integrating digital technologies into classroom instruction.

Distance and hybrid education should offer opportunities for negotiation of role expectations. This research has demonstrated how a lack of transparent, respectful, timely and meaningful communication left students and teachers unaware of each other's needs and capacities, resulting in learning losses and reduced wellbeing. In order to avoid such negative effects of relational mistrust, education in times of crisis and rapid change should offer frequent opportunities for students and teachers to talk about their positions and to jointly define and plan the education process: defining obligations, establishing rules of conduct, planning course schedules, choosing the time and space for support in learning and socio-emotional support, etc. Negotiation of role-relationships 
should be institutionally supported (Louis, 2007; Tennenbaum, 2018) by enabling resources that students and teachers can use as needed (e.g., "learning hubs" for students who struggle with digital learning and lack of interaction during lockdown - Darling-Hammond et al., 2021).

\section{Conclusions}

The aim of this paper was to understand why and how relational trust between students and teachers was challenged during distance and hybrid education in Serbian primary schools. Furthermore, it illuminated niches of role relationships that hold potential for repairing and strengthening trust as they emerge from the data, and offered recommendations for trust-building that target students, teachers and policymakers.

The results showed how students expected to rely on teachers to address uncertainties and resolve ambiguities that distance and hybrid education brought, through coordinated instruction at the school level, creativity and diversity of instruction, provision of support for learning, transparent and just assessment, and caring communication. When teachers met these expectations, students narrate about positive learning outcomes and benefits for their wellbeing; otherwise, they felt overwhelmed, burdened and confused, and narrate about learning losses, etc. Therefore, lapses in resolving uncertainty and ambiguity made students question teachers' competence, credibility, integrity and respect. On the other hand, our research highlighted teachers' experiences in the ruptured education system, their perspectives on relational trust, as well as the structural and institutional conditions that affected their conduct and competence. Considering this, recommendations for trust building suggest raising awareness of both students and teachers about each other's perspectives and their negotiation locally, as well as policy support to create opportunities for trustful student-teacher relationships in the course of emergency distance education and other crises.

Finally, we consider the limitations of our findings and implications for further research. Since the data collection in our study was conducted online, the percentage of narratives obtained from students with limited access to internet and ICT devices is not proportional to the structure of the student body in the chosen schools. Consequently, relational trust of these students and teachers was not well explored. The methodology for future studies on relational trust needs to be more inclusive of students from vulnerable groups. Furthermore, this research did not take into consideration histories of institutional trust and previous accounts of role relationships in the schools from which our sample came, nor 
did it consider teachers' experiences of new technologies in education. Therefore, we were not able to discuss their contribution to the current state of role relationships, even though the relevant literature emphasises its necessity.

\section{References}

Bergdahl, N., \& Nouri, J. (2020). Covid-19 and crisis-promoted distance education in Sweden.

Technology, Knowledge and Learning. https://doi.org/10.1007/s10758-020-09470-6

Bertling, J., Rojas, N., Alegre, J., \& Faherty, K. (2020). A tool to capture learning experiences during Covid-19: The PISA Global Crises Questionnaire Module. OECD Education Working Papers, No. 232.

OECD Publishing. https://doi.org/10.1787/9988df4e-en

Bryk, A. S. (2010). Organising schools for improvement. Phi Delta Kappan, 91(7), 23-30. http://www. pined.info/pdf/8431759374.pdf

Bryk, A., \& Schneider, B. (2002). Trust in schools: A core resource for improvement. Russell Sage Foundation.

Černe, T., \& Juriševič, M. (2018). The self-regulated learning of younger adolescents with and without learning difficulties - A comparative multiple case study. CEPS Journal, 8(4), 9-28. https://doi.

org/10.26529/cepsj.42

Cranston, J. (2011). Relational trust: The glue that binds a professional learning community. Alberta Journal of Educational Research, 57(1), 59-72. http://jmss.org/index.php/ajer/article/view/55455

Daiute, C. (2013). Narrative inquiry: A dynamic approach. SAGE Publications.

Daiute, C., \& Kovač-Cerović, T. (2017). Minority teachers: Roma in Serbia: Narrate education reform. Institute of Psychology.

Daiute, C., Kovács Cerović, T., Mićić, K., Sullu, B., \& Vracar, S. (2020). Dynamic values negotiating geo-political narratives across a migration system. Qualitative Psychology, 7(3), 367-383. https://doi. org/10.1037/qupoooo166.

Darling-Hammond, L., Schachner, A., Edgerton, A. K., Badrinarayan, A., Cardichon, J., Cookson, P. W., \& Griffith, M. (2020). Restarting and reinventing school: Learning in the time of COVID and beyond. Learning Policy Institute. https://learningpolicyinstitute.org/sites/default/files/product-files/ Restart_Reinvent_Schools_COVID_Priority2_Distance_Learning.pdf Goddard, R. D. (2003). Relational networks, social trust, and norms: A social capital perspective on students' chances of academic success. Educational Evaluation and Policy Analysis, 25(1), 59-74. https://doi.org/10.3102/01623737025001059

Goddard, R. D., Tschannen-Moran, M., \& Hoy, W. K. (2001). A multilevel examination of the distribution and effects of teacher trust in students and parents in urban elementary schools. The Elementary School Journal, 102(1), 3-17. https://doi.org/10.1086/49969o Gregory, A., \& Ripski, M. B. (2008). Adolescent trust in teachers: Implications for behavior in the high school classroom. School Psychology Review, 37(3), 337-353. https://doi.org/10.1080/02796015.20 08.12087881 
Gudmundsdottir, G. B., \& Hathaway, D. M. (2020). “We always make it work”: Teachers' agency in the time of crisis. Journal of Technology and Teacher Education, 28(2), 239-250. https://www. learntechlib.org/primary/p/216242/paper_216242.pdf Hanushek, E. (2020). The economic impacts of learning losses. OECD Education Working Papers, No. 225. OECD Publishing. http://www.oecd.org/education/The-economic-impacts-of-coronaviruscovid-19-learning-losses.pdf

Hargreaves, A., \& Fullan, M. (2020). Professional capital after the pandemic: Revisiting and revising classic understandings of teachers' work. Journal of Professional Capital and Community, 5(3/4), 327-336. https://doi.org/10.1108/JPCC-06-2020-0039

Hodges, C., Moore, S., Lockee, B., Trust, T., \& Bond, A. (2020). The difference between emergency remote teaching and online learning. Educause Review. http://www.cetla.howard.edu/workshops/ docs/The\%2oDifference\%2oBetween\%2oEmergency\%2oRemote\%2oTeaching\%2oand\%20Online\%20 Learning\%20_\%2oEDUCAUSE\%2o(2).pdf

Kim, L. E., \& Asbury, K. (2020). 'Like a rug had been pulled from under you': The impact of COVID-19 on teachers in England during the first six weeks of the UK lockdown. British Journal of Educational Psychology, 9o(4), 1062-1083. https://bpspsychub.onlinelibrary.wiley.com/doi/ pdfdirect/10.1111/bjep.12381

Kim, L. E., Learya, R., \& Asbury, K. (2020). 'We need clear directions if we're going to move forward. It's as simple as that': Teachers' narratives during partial school reopenings in the COVID-19 pandemic. University of York, Department of Education. https://psyarxiv.com/m8scj/

Kovacs Cerović, T., Mićić, K., \& Vračar, S. (2021). A leap to the digital era: What are lower and upper secondary school students' experiences of distance education during the COVID-19 pandemic in Serbia? European Journal of Psychology of Education. Advance online publication. https://doi. org/10.1007/s10212-021-00556-y

Kovacs, H. (2018). Change, challenge, transformation: A qualitative inquiry into transformative teacher learning. CEPS Journal, 8(3), 99-118.https://doi.org/10.26529/cepsj.510

Lee, J. C. K., Zhang, Z., \& Yin, H. (2011). A multilevel analysis of the impact of a professional learning community, faculty trust in colleagues and collective efficacy on teacher commitment to students. Teaching and Teacher Education, 27(5), 820-830. https://www.sciencedirect.com/science/article/pii/ So742051X11000072

Loades, M. E., Chatburn, E., Higson-Sweeney, N., Reynolds, S., Shafran, R., Brigden, A., Linney, K., Niamh McManus, M., \& Crawley, E. (2020). Rapid systematic review: The impact of social isolation and loneliness on the mental health of children and adolescents in the context of COVID-19. Journal of the American Academy of Child \& Adolescent Psychiatry, 59(11), 1218-1239. https://doi.org/10.1016/j. jaac.2020.05.009

Louis, K. S. (2007). Trust and improvement in schools. Journal of Educational Change, 8(1), 1-24. https://link.springer.com/article/10.1007/s10833-006-9015-5 McMahon, D. D., \& Walker, Z. (2019). Leveraging emerging technology to design an inclusive future with universal design for learning. CEPS Journal, 9(3), 75- 93. https://doi.org/10.26529/cepsj.639 
Moss, G., Allen, R., Bradbury, A., Duncan, S., Harmey, S., \& Levy, R. (2020). Primary teachers' experience of the COVID-19 lockdown - Eight key messages for policymakers going forward. UCL Institute of Education.

Myung, J., \& Kimner, H. (2020). Continuous improvement in schools in the COVID-19 context: A summary brief. Policy Analysis for California Education. https://edpolicyinca.org/sites/default/ files/2020-o9/pb_myung_sep2020.pdf

Niemi, H. M., \& Kousa, P. (2020). A case study of students' and teachers' perceptions in a Finnish high school during the COVID pandemic. International Journal of Technology in Education and Science (IJTES), 4(4), 352-369. https://doi.org/10.46328/ijtes.v4i4.167

Orgilés, M., Morales, A., Delvecchio, E., Mazzeschi, C., \& Espada, J. P. (2020). Immediate psychological effects of the COVID-19 quarantine in youth from Italy and Spain. Frontiers in Psychology, 11, 579038. https://doi.org/10.3389/fpsyg.2020.579038

Reimers, F. M., \& Schleicher, A. (2020). A framework to guide an education response to the COVID-19 pandemic of 2020. OECD Publishing. https://oecd.dam-broadcast.com/pm_7379_126_126988t63lxosohs.pdf

Schleicher, A. (2020). The impact of COVID-19 on education: Insights from education at a glance 2020. OECD Publishing. https://www.oecd.org/education/the-impact-of-covid-19-on-education-insightseducation-at-a-glance-2020.pdf

Tennenbaum, S. (2018). Relational Trust within an urban public comprehensive high school district in Northern California (Publication number 21) (Doctoral dissertation). SJSU Scholar Works. https:// scholarworks.sjsu.edu/etd_dissertations/21/

Trust, T., \& Whalen, J. (2020). Should teachers be trained in emergency remote teaching? Lessons learned from the COVID-19 pandemic. Journal of Technology and Teacher Education, 28(2), 189-199. https://www.learntechlib.org/primary/p/215995/paper_215995.pdf

Tschannen-Moran, M. (2009). Fostering teacher professionalism in schools: The role of leadership orientation and trust. Educational Administration Quarterly, 45(2), 217-247. https://doi. org/10.1177/0013161X08330501

Tschannen-Moran, M., \& Gareis, C. R. (2015). Principals, trust, and cultivating vibrant schools. Societies, 5(2), 256-276. https://www.mdpi.com/2075-4698/5/2/256/pdf UN. (2020, August). Policy brief: Education during COVID-19 and beyond. https://www.un.org/ development/desa/dspd/wp-content/uploads/sites/22/2020/o8/sg_policy_brief_covid-19_and_ education_august_2020.pdf

UNESCO. (2020a). Education: From disruption to recovery. UNESCO. https://en.unesco.org/covid19/ educationresponse

UNESCO. (2020b, April). Distance learning strategies in response to COVID-19 school closures (Issue

Note 2.1). UNESCO Education Sector. https://unesdoc.unesco.org/ark:/48223/pfoooo373305 UNICEF. (2020). Covid-19: Are children able to continue learning during school closures? A global analysis of the potential reach of remote learning policies using data from 100 countries. UNICEF. https://data.unicef.org/wp-content/uploads/2020/11/RemoteLearningFactsheet_Updated.pdf 
Van der Spoel, I., Noroozi, O., Schuurink, E., \& van Ginkel, S. (2020). Teachers' online teaching expectations and experiences during the Covid-19 pandemic in the Netherlands. European Journal of Teacher Education, 43(4), 623-638. https://doi.org/10.1080/02619768.2020.1821185

Van Maele, D., \& Van Houtte, M. (2011). The quality of school life: Teacher-student trust relationships and the organizational school context. Social Indicators Research, 100(1), 85-100. https://link.springer. com/content/pdf/10.1007/s11205-010-9605-8.pdf

Viner, R. M., Bonell, C., Drake, L., Jourdan, D., Davies, N., Baltag, V., Jerrim, J., Proimos, J., \& Darzi, A. (2021). Reopening schools during the COVID-19 pandemic: Governments must balance the uncertainty and risks of reopening schools against the clear harms associated with prolonged closure. Archives of Disease in Childhood, 106(2), 111-113. https://adc.bmj.com/content/archdischild/106/2/111.full.pdf Vivitsou, M. (2019). Digitalisation in education, allusions and references. CEPS Journal, 9(3), 117-136. https://doi.org/10.26529/cepsj.706

Weinstein, J., Raczynski, D., \& Peña, J. (2020). Relational trust and positional power between school principals and teachers in Chile: A study of primary schools. Educational Management Administration \& Leadership, 48(1), 64-81. https://journals.sagepub.com/doi/ full/10.1177/1741143218792912

\section{Biographical note}

TiJANa Jokić Zorkić, psychologist, a PhD student and a researcher in the Centre for Education Policy, Belgrade, Serbia. The fields of her research are inclusion and diversity in education, appropriation of education policy, and qualitative methodology in educational research.

Katarina Mićić, MA, is a PhD student and a researcher at the Faculty of Philosophy, University of Belgrade, Serbia. Her main areas of research are inclusive education, sociocultural aspects of learning mathematics, and equity in education focusing on gender and minority issues.

Tünde Kovács Cerović, PhD, is associate professor of Educational Psychology and Policy, and a researcher at Belgrade University. Her research studies and publications primarily address the excluded and vulnerable, such as education of Roma, migrants, refugees, and children living in poverty or under unusual circumstances. In addition, she served as Assistent Minister and State Secetary of Education, as Education Advisory Board member for Open Society Foundations, and was education consultant for several international organizations. 